\title{
Virulence and Molecular Polymorphism in International Collections of the Wheat Leaf Rust Fungus Puccinia triticina
}

\author{
J. A. Kolmer and J. Q. Liu
}

First author: USDA-ARS, Department of Plant Pathology, North Carolina State University, Raleigh 27607-7631; and second author: AgrEvo Canada, 203-407 Downey Road, Saskatoon, SK R7N 4L8, Canada.

Accepted for publication 16 December 1999.

\begin{abstract}
Kolmer, J. A., and Liu, J. Q. 2000. Virulence and molecular polymorphism in international collections of the wheat leaf rust fungus Puccinia triticina. Phytopathology 90:427-436.

Collections of Puccinia triticina, the wheat leaf rust fungus, were obtained from Great Britain, Slovakia, Israel, Germany, Australia, Italy, Spain, Hungary, South Africa, Uruguay, New Zealand, Brazil, Pakistan, Nepal, and eastern and western Canada. All single-uredinial isolates derived from the collections were tested for virulence polymorphism on 22 Thatcher wheat lines that are near-isogenic for leaf rust resistance genes. Based on virulence phenotype, selected isolates were also tested for randomly amplified polymorphic DNA (RAPD) using 11 primers. The national collections were placed into 11 groups based on previously established epidemiological zones. Among the 131 single-uredinial isolates, 105 virulence phenotypes and 82 RAPD phenotypes were described. In a modified analysis of variance, $26 \%$ of the virulence variation was due to differences in isolates between groups, with the remainder attributable to differences
\end{abstract}

ABSTRACT

Leaf rust (Puccinia triticina Eriks. $=P$. recondita f. sp. tritici $[1])$ is a common pathogen of wheat (Triticum aestivum L.) found in many diverse wheat-growing areas throughout the world. Saari and Prescott (26) broadly defined different epidemiological zones of wheat leaf rust: Mexico; the United States and Canada; southern Asia; western Asia; eastern Europe and Egypt; southern Africa; North Africa and western Europe; the Far East; southeastern Asia; South America; and Australia and New Zealand. These groupings were mostly determined by a combination of global geographical features and patterns of the prevailing winds that influence dispersal and spread of urediniospores. Regional collections within countries have also been described. Kolmer $(13,15)$ described distinct collections of $P$. triticina in eastern and western Canada based on virulence phenotypes. Leonard et al. (19) showed that different virulence phenotypes could be found in geographical areas of the United States. Collections of $P$. triticina in western and eastern Europe were shown to differ for predominant virulence phenotypes (24).

Collections of $P$. triticina in North America and generally throughout the world reproduce asexually (27). The principle alternate host of $P$. triticina, Thalictrum speciosissimum L. $(1,27)$, is not found in North America or most parts of the world. Infected T. speciosissimum plants have been described in Portugal (7). Thalictrum species native to North America are resistant to basidiospore infection (5). There are, however, isolated reports of $P$. triticina aecio-

Corresponding author: J. A. Kolmer; E-mail address: james_kolmer@ncsu.edu

This research was conducted while both authors were employed at the Agriculture and AgriFood Canada Cereal Research Centre, Winnipeg, Manitoba, R3T 2M9, Canada.

Publication no. P-2000-0217-04R

This article is in the public domain and not copyrightable. It may be freely reprinted with customary crediting of the source. The American Phytopathological Society, 2000. within groups. Of the RAPD variation, $36 \%$ was due to differences in isolates between groups. Clustering based on the average virulence distance (simple distance coefficient) within and between groups resulted in eight groups that differed significantly. Collections from Australia-New Zealand, Spain, Italy, and Britain did not differ significantly for virulence. Clustering of RAPD marker differences (1 - Dice coefficient) distinguished nine groups that differed significantly. Collections from Spain and Italy did not differ significantly for RAPD variation, neither did collections from western Canada and South America. Groups of isolates distinguished by avirulent/virulent infection types to wheat lines with resistance genes $L r 1, L r 2 a, L r 2 c$, and $L r 3$ also differed significantly for RAPD distance, showing a general relationship between virulence and RAPD phenotype. The results indicated that on a worldwide level collections of $P$. triticina differ for virulence and molecular backgrounds.

Additional keywords: host selection, physiologic specialization, Puccinia recondita f. sp. tritici.

spores pathogenic to wheat found on native North American Thalictrum species (20). In most parts of the world, sexual reproduction is not epidemiologically important. There is also little or no evidence indicating that sexual reproduction plays an important role in generating new genotypes of $P$. triticina, although this possibility cannot be discounted entirely.

In a previous study, Kolmer et al. (18) showed that isolates of $P$. triticina in eastern and western Canada that differed for virulence phenotype also differed for molecular background. There was a general relationship between the virulence phenotypes and molecular phenotypes of isolates in the two different populations. The asexual reproduction of $P$. triticina in North America maintains strong associations between virulence and molecular polymorphisms within distinct groups of the leaf rust fungus. The objectives of this study were to compare virulence and random amplified polymorphic DNA (RAPD) phenotypes of $P$. triticina collections from different parts of the world and to determine if the same general relationship between the two markers characteristic of the North American populations is also characteristic of isolates from various countries.

\section{MATERIALS AND METHODS}

P. triticina isolates. Collections of the wheat leaf rust fungus were obtained from the following countries courtesy of the listed cooperators: Britain, R. Johnson; Slovakia, P. Bartos; Israel, J. Manisterski; Germany, U. Walther; Australia, R. Park; Italy, F. Cassulli; Spain, D. Rubiales; Hungary, K. Manninger; South Africa, Z. Pretorius; Uruguay, S. German; and Brazil, A. Barcellos. The collections were representative of $P$. triticina virulence phenotypes in these countries as determined by virulence surveys conducted by the cooperators. Collections of $P$. triticina from New Zealand were sampled from wheat-breeding plots at Christchurch in 1996. Isolates from Pakistan and Nepal were obtained from D. Long of 
TABLE 1. Designations ${ }^{\mathrm{a}}$, virulence phenotypes ${ }^{\mathrm{b}}$, and random amplified polymorphic DNA (RAPD) phenotypes ${ }^{\mathrm{c}}$ of an international collection of Puccinia triticina isolates

\begin{tabular}{|c|c|c|c|c|}
\hline $\begin{array}{l}\text { Isolate } \\
\text { designation }\end{array}$ & Virulences & $\begin{array}{l}\text { Virulence } \\
\text { phenotype }\end{array}$ & $\begin{array}{c}\text { RAPD } \\
\text { phenotype }\end{array}$ & $\begin{array}{l}\text { RAPD phenotype } \\
\text { number }\end{array}$ \\
\hline AUST 4 & $\mathrm{~B}, 10,14 \mathrm{~b}, 20,23$ & BBBNML & 100110110001100 & 53 \\
\hline AUST 2-1 & $2 c, B, 10,14 b, 23$ & DBBNLL & 100010010001001 & 33 \\
\hline AUST 3-3-1 & $1,26,11,10,14 a, 14 b, 15,23,28$ & LCGFQQ & 000011001011001 & 12 \\
\hline AUST 7 & $1,2 \mathrm{c}, 3, \mathrm{~B}, 3 \mathrm{bg}, 10,14 \mathrm{a}, 14 \mathrm{~b}, 23$ & PBBTLL & 111110010011100 & 79 \\
\hline AUST 1 & $1,2 \mathrm{a}, 2 \mathrm{c}, \mathrm{B}, 10,14 \mathrm{a}, 14 \mathrm{~b}, 15,20,23$ & SBBPRL & 100010010001000 & 32 \\
\hline AUST 8 & $1,2 \mathrm{a}, 2 \mathrm{c}, 3, \mathrm{~B}, 3 \mathrm{bg}, 10,14 \mathrm{a}, 14 \mathrm{~b}, 15,20,23$ & TBBTRL & 111110010011100 & 79 \\
\hline NZ 5-1 & $14 \mathrm{a}, 14 \mathrm{~b}, 15,20$ & BBBCRB & 000011001001100 & 10 \\
\hline NZ 2-1-1 & $2 \mathrm{c}, \mathrm{B}, 10,14 \mathrm{~b}, 20,23$ & DBBNML & 101010000011101 & 60 \\
\hline NZ 3-2 & $2 c, B, 10,14 b$ & DBBNLB & 100110011001100 & 49 \\
\hline NZ 5-2 & $1,26,11,10,14 \mathrm{a}, 14 \mathrm{~b}, 15,18,23,28$ & LCGFSQ & 000011001011000 & 11 \\
\hline NZ 1-1 & $1,2 \mathrm{c}, 3, \mathrm{~B}, 10,14 \mathrm{a}, 14 \mathrm{~b}, 20$ & PBBPMB & 100010000001000 & 29 \\
\hline NZ 12-1 & $1,2 \mathrm{c}, 3, \mathrm{~B}, 10,14 \mathrm{a}, 14 \mathrm{~b}, 20$ & PBBPMB & 100010010001000 & 32 \\
\hline NZ 14-3 & $1,2 \mathrm{c}, 3, \mathrm{~B}, 10,14 \mathrm{a}, 14 \mathrm{~b}, 20$ & PBBPMB & 111010010001000 & 73 \\
\hline NZ 10-2 & $1,2 \mathrm{c}, 3, \mathrm{~B}, 3 \mathrm{bg}, 10,14 \mathrm{a}, 14 \mathrm{~b}, 20$ & РВBTMB & 100110010011100 & 45 \\
\hline NZ 13-3 & $1,2 \mathrm{c}, 3, \mathrm{~B}, 3 \mathrm{bg}, 10,14 \mathrm{a}, 14 \mathrm{~b}, 20,23$ & PBBTML & 100110010011100 & 45 \\
\hline NZ 8-1 & $1,2 \mathrm{a}, 2 \mathrm{c}, 3,24, \mathrm{~B}, 10,14 \mathrm{a}, 14 \mathrm{~b}, 15,20,23,28$ & TDBPRQ & 000011001011100 & 13 \\
\hline PAK 4060 & $1,3,10,14 \mathrm{a}, 14 \mathrm{~b}, 15,20,23,28$ & MBBFRQ & 111111011011101 & 82 \\
\hline PAK 4074 & $1,2 \mathrm{c}, \mathrm{B}, 10,14 \mathrm{~b}, 20$ & NBBNMB & 100110011001101 & 50 \\
\hline PAK 4083 & $1,2 \mathrm{c}, 3, \mathrm{~B}, 3 \mathrm{bg}, 10,14 \mathrm{a}, 14 \mathrm{~b}, 23$ & PBBTLL & 101110010001101 & 65 \\
\hline PAK 4032 & $1,2 \mathrm{c}, 3, \mathrm{~B}, 3 \mathrm{bg}, 10,14 \mathrm{a}, 14 \mathrm{~b}, 18,23$ & PBBTNL & 101110010011101 & 67 \\
\hline PAK 4001-1 & $1,2 \mathrm{c}, 3,26, \mathrm{~B}, 3 \mathrm{bg}, 10,14 \mathrm{a}, 14 \mathrm{~b}, 23$ & PCBTLL & 100110010011100 & 45 \\
\hline PAK 4063-1 & $1,2 \mathrm{a}, 2 \mathrm{c}, 26,17,10,14 \mathrm{a}, 14 \mathrm{~b}, 18,20,23,28$ & SCDFRQ & 000011001011000 & 11 \\
\hline PAK 4041 & $1,2 \mathrm{a}, 2 \mathrm{c}, 26,17,10,14 \mathrm{a}, 14 \mathrm{~b}, 15,18,20,23,28$ & SCDFTQ & 000111001011001 & 18 \\
\hline NPL 4029 & $1,2 \mathrm{a}, 2 \mathrm{c}, 3,11,17,3 \mathrm{bg}, 10,14 \mathrm{a}, 15,20$ & ТВЈКНВ & 100010001001101 & 31 \\
\hline NPL 4033 & $1,2 \mathrm{a}, 2 \mathrm{c}, 3,11,17,3 \mathrm{bg}, 10,14 \mathrm{a}, 14 \mathrm{~b}, 15,23$ & TBJKQL & 100010001001100 & 30 \\
\hline NPL 4110-1 & $1,2 \mathrm{a}, 2 \mathrm{c}, 3,16,11,17,3 \mathrm{bg}, 10,14 \mathrm{a}, 14 \mathrm{~b}, 15,20$ & TGJKRB & 100010001001100 & 30 \\
\hline CA1 52-1 & $3,26,17,10,14 a, 14 b, 15,20,23$ & CCDFRL & 100011011011000 & 35 \\
\hline CA1 12-3 & $1,3,17, \mathrm{~B}, 3 \mathrm{bg}, 10,14 \mathrm{a}, 14 \mathrm{~b}, 15,20,23$ & MBDTRL & 000010001011100 & 7 \\
\hline CA1 50-1 & $1,3,3 \mathrm{ka}, 11,10,14 \mathrm{a}, 14 \mathrm{~b}, 15,20,23,28$ & MBQFRQ & 000011001011100 & 13 \\
\hline CA1 39-2 & $1,3,3 \mathrm{ka}, 11,30,10,14 \mathrm{a}, 14 \mathrm{~b}, 15,20,23,28$ & MBRFRQ & 000011001011100 & 13 \\
\hline CA1 1-2 & $1,3,26,17, \mathrm{~B}, 3 \mathrm{bg}, 10,14 \mathrm{a}, 14 \mathrm{~b}, 15,20,23$ & MCDTRL & 000010001011100 & 7 \\
\hline CA1 43-1 & $1,3,24,3 \mathrm{ka}, 11,30,10,14 \mathrm{a}, 14 \mathrm{~b}, 15,23,28$ & MDRFRQ & 000011001011100 & 13 \\
\hline CA1 56-1 & $1,3,24,26,3 \mathrm{ka}, 30,10,14 \mathrm{a}, 14 \mathrm{~b}, 15,20,23,28$ & MFMFRQ & 000011001011100 & 13 \\
\hline CA1 74-2 & $1,3,16,10,14 \mathrm{a}, 14 \mathrm{~b}, 15,20,23,28$ & MGBFRQ & 000011001011100 & 13 \\
\hline CA1 35-1 & $1,3,16,24,10,14 \mathrm{a}, 14 \mathrm{~b}, 15,20,23,28$ & MJBFRQ & 000011001011100 & 13 \\
\hline CA1 36-3 & $1,2 \mathrm{a}, 2 \mathrm{c}, 3,24,11,10,14 \mathrm{a}, 14 \mathrm{~b}, 15,20,23,28$ & TDGFRQ & 000011001011100 & 13 \\
\hline CA1 77-2 & $1,2 \mathrm{a}, 2 \mathrm{c}, 3,16,24,10,14 \mathrm{a}, 14 \mathrm{~b}, 15,20,23,28$ & TJBFRQ & 000011001011100 & 13 \\
\hline CA2 109-2 & $2 \mathrm{c}, 3,3 \mathrm{ka}, 30, \mathrm{~B}, 14 \mathrm{a}, 14 \mathrm{~b}, 15,20,23$ & FBMMRL & 100110010111000 & 48 \\
\hline CA2 38-2 & $1,2 \mathrm{c}, 3,17, \mathrm{~B}, 3 \mathrm{bg}, 15,20,23,28$ & PBDQHQ & 000110001111100 & 16 \\
\hline CA2 109-1 & $1,2 \mathrm{c}, 3,11,3 \mathrm{bg}, 14 \mathrm{a}, 14 \mathrm{~b}, 15,20,23,28$ & PBGHRQ & 100011000111000 & 34 \\
\hline CA2 134-3 & $1,2 \mathrm{c}, 3,3 \mathrm{ka}, \mathrm{B}, 10,14 \mathrm{~b}, 15,20,23,28$ & PBLHRQ & 111100010111001 & 76 \\
\hline CA2 114-1 & $1,2 \mathrm{c}, 3,3 \mathrm{ka}, 30, \mathrm{~B}, 14 \mathrm{a}, 14 \mathrm{~b}, 15,18,20,23,28$ & PBMMTQ & 100111000111000 & 57 \\
\hline CA2 104-2 & $1,2 \mathrm{c}, 3,3 \mathrm{ka}, 11,30, \mathrm{~B}, 3 \mathrm{bg}, 10,14 \mathrm{~b}, 15,18,20,23,28$ & PBRSTQ & 111110010111000 & 80 \\
\hline CA2 195-2 & $1,2 \mathrm{c}, 3,26,3 \mathrm{ka}, 11,30, \mathrm{~B}, 3 \mathrm{bg}, 10,14 \mathrm{~b}, 15,18,20,23,28$ & PCRSTQ & 111110010111001 & 81 \\
\hline CA2 124-3 & $1,2 \mathrm{a}, 2 \mathrm{c}, 17,10,14 \mathrm{~b}, 15,20,28$ & SBDDRG & 011110001011000 & 27 \\
\hline CA2 71-2 & $1,2 \mathrm{a}, 2 \mathrm{c}, 3,24,3 \mathrm{ka}, 11,17,30, \mathrm{~B}, 3 \mathrm{bg}, 14 \mathrm{a}, 15,28$ & TDTRGG & 000010000011100 & 1 \\
\hline DL 24-9-2 & $\mathrm{B}, 10,14 \mathrm{~b}, 23$ & BBBNLL & 100110100101100 & 52 \\
\hline DL 24-4-2 & $2 \mathrm{c}, 3,3 \mathrm{ka}, 30, \mathrm{~B}, 3 \mathrm{bg}, 10,14 \mathrm{a}, 14 \mathrm{~b}, 23$ & FBMTLL & 111110001011100 & 78 \\
\hline DL 62-1-1 & $1,2 \mathrm{a}, 2 \mathrm{c}, 11,17,14 \mathrm{~b}, 15,20,23$ & SBJBRL & 011010001011100 & 23 \\
\hline HG 4-2 & $3,26,3 \mathrm{bg}, 10,14 \mathrm{a}, 14 \mathrm{~b}, 15,20,23,28$ & CCBKRQ & 011011001011100 & 25 \\
\hline HG 1-1 & $2 \mathrm{c}, 3, \mathrm{~B}, 3 \mathrm{bg}, 10,14 \mathrm{~b}, 15,18,20,23,28$ & FBBSTQ & 100111001011000 & 58 \\
\hline HG 9-1 & $1,3,24,26,3 \mathrm{ka}, 30,10,14 \mathrm{a}, 14 \mathrm{~b}, 15,20,23,28$ & MFMFRQ & 000010001001101 & 3 \\
\hline HG 4-1 & $1,2 \mathrm{a}, 2 \mathrm{c}, 3,17,3 \mathrm{bg}, 10,14 \mathrm{a}, 14 \mathrm{~b}, 15,18,20,23,28$ & TBDKTQ & 000011001011100 & 13 \\
\hline HG 10-2 & $1,2 \mathrm{a}, 2 \mathrm{c}, 3,26,11,17,3 \mathrm{bg}, 15,20,23$ & TCJGHL & 000010001010100 & 4 \\
\hline HG 2-1 & $1,2 \mathrm{a}, 2 \mathrm{c}, 3,26,3 \mathrm{ka}, 11,17,30,3 \mathrm{bg}, 15,20$ & TCTGHB & 000010001010100 & 4 \\
\hline HG 3-2 & $1,2 \mathrm{a}, 2 \mathrm{c}, 3,26,3 \mathrm{ka}, 11,17,30,3 \mathrm{bg}, 15,20,23$ & TCTGHL & 000010001010101 & 5 \\
\hline SK 2-2 & $3,26,3 \mathrm{ka}, 17,30, \mathrm{~B}, 3 \mathrm{bg}, 14 \mathrm{~b}, 15,28$ & CCPQQG & 101010011011100 & 62 \\
\hline SK 4-2 & $3,26,3 \mathrm{ka}, 17,30, \mathrm{~B}, 3 \mathrm{bg}, 14 \mathrm{~b}, 15,20,23$ & CCPQRL & 001010000011100 & 20 \\
\hline SK 7-1 & $3,26,3 \mathrm{ka}, 17,30, \mathrm{~B}, 3 \mathrm{bg}, 14 \mathrm{a}, 15,23$ & CCPRGL & 101010000011101 & 59 \\
\hline SK 8-2 & $3,26,3 \mathrm{ka}, 17,30, \mathrm{~B}, 3 \mathrm{bg}, 14 \mathrm{a}, 15,20,23$ & CCPRHL & 000010000011101 & 2 \\
\hline SK 9-2 & $3,26,3 \mathrm{ka}, 17,30, \mathrm{~B}, 3 \mathrm{bg}, 14 \mathrm{a}, 14 \mathrm{~b}, 15,23$ & CCPRQL & 101110011011100 & 69 \\
\hline SK 6-1 & $1,2 \mathrm{a}, 2 \mathrm{c}, 3,26,3 \mathrm{ka}, 17,30,3 \mathrm{bg}, 14 \mathrm{a}, 15,18$ & ТСРНЈВ & 000010001001101 & 3 \\
\hline
\end{tabular}

SK 6-1

$1,2 \mathrm{a}, 2 \mathrm{c}, 3,26,3 \mathrm{ka}, 17,30,3 \mathrm{bg}, 14 \mathrm{a}, 15,18$

(continued on the next page)

a AUST $=$ Australia, NZ = New Zealand, PAK $=$ Pakistan, NPL = Nepal, CA1 $=$ Canada -1, CA2 $=$ Canada -2, DL $=$ Germany, HG $=$ Hungary, SK $=$ Slovakia, ES $=$ Spain, IS = Israel, IT = Italy, GB = Great Britain, UR = Uruguay, and SF = South Africa.

b As determined by virulent or avirulent infection types to near-isogenic lines of Thatcher wheat with resistance genes $L r 1, L r 2 a, L r 2 c, L r 3, L r 9, L r 16, L r 24$, Lr26, Lr3ka, Lr11, Lr17, Lr30, LrB, Lr3bg, Lr10, Lr14a, Lr14b, Lr15, Lr18, Lr20, Lr23, and Lr28.

c As determined by presence of absence of 15 polymorphic DNA bands generated by 10-base DNA primers UBC 402, UBC 450, UBC 489, UBC 517, UBC 519, UBC 521, UBC 538, UBC 556, UBC 889, OPR2, and CRC 12. 
TABLE 1. (continued from the preceding page)

\begin{tabular}{|c|c|c|c|c|}
\hline $\begin{array}{l}\text { Isolate } \\
\text { designation }\end{array}$ & Virulences & $\begin{array}{l}\text { Virulence } \\
\text { phenotype }\end{array}$ & $\begin{array}{c}\text { RAPD } \\
\text { phenotype }\end{array}$ & $\begin{array}{l}\text { RAPD phenotype } \\
\text { number }\end{array}$ \\
\hline ES 22-1 & $2 c, 10,14 b, 20,23$ & DBBDML & 100100010101100 & 39 \\
\hline ES 1-1 & $2 c, 10,14 b, 20,23$ & DBBDML & 100100010101101 & 40 \\
\hline ES 23-2 & $2 \mathrm{c}, \mathrm{B}, 10,14 \mathrm{~b}, 20,23$ & DBBNML & 100100010001100 & 36 \\
\hline ES $15-1$ & $2 \mathrm{c}, 3,3 \mathrm{ka}, 30, \mathrm{~B}, 3 \mathrm{bg}, 10,14 \mathrm{a}, 14 \mathrm{~b}$ & FBMTLB & 100110010011100 & 44 \\
\hline ES 9-1 & $2 \mathrm{c}, 3,16,17, \mathrm{~B}, 3 \mathrm{bg}, 10,14 \mathrm{~b}$ & FGDSLB & 100110010001100 & 43 \\
\hline ES 14-1 & $2 \mathrm{c}, 3,16,17, \mathrm{~B}, 3 \mathrm{bg}, 10,14 \mathrm{a}, 14 \mathrm{~b}, 23$ & FGDTLL & 100110010101001 & 47 \\
\hline ES 21-2 & $1,3,17,3 \mathrm{bg}, 10,14 \mathrm{a}, 14 \mathrm{~b}, 15,20,23,28$ & MBDKRQ & 011001001011100 & 22 \\
\hline IS J-1 & $10,14 b, 15,18,23$ & BBBDSL & 100100010101000 & 38 \\
\hline IS $745-1$ & $\mathrm{~B}, 10,14 \mathrm{~b}, 23$ & BBBNLL & 100100110001000 & 41 \\
\hline IS $770-2$ & $1,26,11,10,14 \mathrm{a}, 14 \mathrm{~b}, 15,18,23,28$ & LCGFSQ & 000011001111000 & 14 \\
\hline IS M-2 & $1,2 \mathrm{c}, 3, \mathrm{~B}, 3 \mathrm{bg}, 10,14 \mathrm{~b}, 23$ & PBBSLL & 100110010011100 & 45 \\
\hline IS F-1 & $1,2 \mathrm{c}, 3, \mathrm{~B}, 3 \mathrm{bg}, 10,14 \mathrm{~b}, 18,23$ & PBBSNL & 100110010011100 & 45 \\
\hline IS L-2 & $1,2 \mathrm{c}, 3,3 \mathrm{ka}, 30, \mathrm{~B}, 3 \mathrm{bg}, 10,14 \mathrm{~b}, 23$ & PBMSLL & 100110010011100 & 45 \\
\hline IS E-1 & $1,2 \mathrm{c}, 3,3 \mathrm{ka}, 30, \mathrm{~B}, 3 \mathrm{bg}, 10,14 \mathrm{~b}, 20$ & PBMSMB & 100110010011100 & 45 \\
\hline IS D-1 & $1,2 \mathrm{a}, 2 \mathrm{c}, 3,3 \mathrm{ka}, 30, \mathrm{~B}, 3 \mathrm{bg}, 10,14 \mathrm{~b}, 15,23$ & TBMSQL & 100110010011100 & 45 \\
\hline IS C-1 & $1,2 \mathrm{a}, 2 \mathrm{c}, 3,26, \mathrm{~B}, 3 \mathrm{bg}, 14 \mathrm{~b}, 18,23$ & TCBQNL & 111110010011100 & 79 \\
\hline IS G-1 & $1,2 \mathrm{a}, 2 \mathrm{c}, 3,26, \mathrm{~B}, 3 \mathrm{bg}, 10,14 \mathrm{~b}, 18,23$ & TCBSNL & 100110010011100 & 45 \\
\hline IS $744-1$ & $1,2 \mathrm{a}, 2 \mathrm{c}, 3,26,17, \mathrm{~B}, 3 \mathrm{bg}, 10,14 \mathrm{a}, 14 \mathrm{~b}, 23$ & TCDTLL & 100110000111100 & 42 \\
\hline IT $1-2$ & $2 \mathrm{c}, 10,14 \mathrm{~b}, 20,23$ & DBBDML & 100100010101101 & 40 \\
\hline IT $1-1$ & $2 \mathrm{c}, 10,14 \mathrm{a}, 14 \mathrm{~b}, 23$ & DBBFLL & 100100010101101 & 40 \\
\hline IT 7-1 & $2 \mathrm{c}, 10,14 \mathrm{a}, 14 \mathrm{~b}, 20,23$ & DBBFML & 100100010101000 & 38 \\
\hline IT $2-2$ & $2 \mathrm{c}, 10,14 \mathrm{a}, 14 \mathrm{~b}, 20,23$ & DBBFML & 100100010101100 & 39 \\
\hline IT 2-1 & $2 \mathrm{c}, 10,14 \mathrm{a}, 14 \mathrm{~b}, 20,23$ & DBBFML & 100100010101101 & 40 \\
\hline IT $15-1$ & $2 \mathrm{c}, 10,14 \mathrm{a}, 14 \mathrm{~b}, 18,20,23$ & DBBFPL & 101100010101101 & 64 \\
\hline IT $10-2$ & $2 \mathrm{c}, \mathrm{B}, 10,14 \mathrm{a}, 14 \mathrm{~b}, 20$ & DBBPMB & 100100010001101 & 37 \\
\hline IT 14-1 & $2 \mathrm{c}, 3,3 \mathrm{ka}, 30, \mathrm{~B}, 3 \mathrm{bg}, 14 \mathrm{a}, 14 \mathrm{~b}, 15,20,23$ & FBMRRL & 101110010011101 & 66 \\
\hline IT $12-2$ & $2 \mathrm{c}, 3,3 \mathrm{ka}, 30, \mathrm{~B}, 3 \mathrm{bg}, 10,14 \mathrm{a}, 14 \mathrm{~b}, 23$ & FBMTLL & 000110010011101 & 17 \\
\hline IT 4-1 & $2 \mathrm{c}, 3,26,3 \mathrm{ka}, 30, \mathrm{~B}, 3 \mathrm{bg}, 10,14 \mathrm{a}, 14 \mathrm{~b}, 15$ & FCMTQB & 100110010011101 & 46 \\
\hline BR 39 & $3,16,3 \mathrm{ka}, 11,17,30,14 \mathrm{a}, 14 \mathrm{~b}, 15,23,28$ & CGTCQQ & 000011001011100 & 13 \\
\hline BR 27 & $1,26,10,14 a, 14 b, 15,20,23,28$ & LCBFRQ & 000010001011000 & 6 \\
\hline BR 25 & $1,26,11,10,14 \mathrm{a}, 14 \mathrm{~b}, 15,18,23,28$ & LCGFSQ & 011011001011000 & 24 \\
\hline BR 26 & $1,3,3 \mathrm{ka}, 11,30,10,14 \mathrm{a}, 14 \mathrm{~b}, 15,20,23,28$ & MBRFRQ & 010011011011100 & 21 \\
\hline BR 37 & $1,2 \mathrm{a}, 2 \mathrm{c}, 9,11,14 \mathrm{a}, 14 \mathrm{~b}, 15,23,28$ & SLGCQQ & 000011001011000 & 11 \\
\hline BR 38 & $1,2 \mathrm{a}, 2 \mathrm{c}, 3,3 \mathrm{bg}, 14 \mathrm{~b}, 15,20,23,28$ & TBBGRQ & 011011001011100 & 25 \\
\hline BR 29 & $1,2 \mathrm{a}, 2 \mathrm{c}, 3,24,26,3 \mathrm{ka}, 11,17,30,3 \mathrm{bg}, 14 \mathrm{a}, 15,28$ & TFTHGG & 000010001011100 & 7 \\
\hline BR 33 & $1,2 \mathrm{a}, 2 \mathrm{c}, 3,16,17,3 \mathrm{bg}, 14 \mathrm{~b}, 15,20,28$ & TGDGRG & 000010000011100 & 1 \\
\hline UR 5-3 & $1,11, \mathrm{~B}, 10,14 \mathrm{a}, 14 \mathrm{~b}, 15,18,23,28$ & LBGPSQ & 000111001011101 & 19 \\
\hline UR 29-2 & $1,26,11,10,14 \mathrm{a}, 14 \mathrm{~b}, 15,18,23,28$ & LCGFSQ & 000011001011000 & 11 \\
\hline UR 14-1 & $1,3,11,3 \mathrm{bg}, 10,14 \mathrm{a}, 15,20,23,28$ & MBGKHQ & 000011001011100 & 13 \\
\hline UR 30-2 & $1,3,11, \mathrm{~B}, 3 \mathrm{bg}, 10,14 \mathrm{a}, 15,23,28$ & MBGTGQ & 000011001011000 & 11 \\
\hline UR 28-3 & $1,3,26,3 \mathrm{ka}, 11,30, \mathrm{~B}, 10,14 \mathrm{a}, 14 \mathrm{~b}, 15,23,28$ & MCRPQQ & 000011001011100 & 13 \\
\hline UR 19-3 & $1,3,26,3 \mathrm{ka}, 11,30, \mathrm{~B}, 10,14 \mathrm{a}, 14 \mathrm{~b}, 15,23,28$ & MCRPQQ & 011011001011100 & 25 \\
\hline UR 42-1 & $1,3,24,26,3 \mathrm{ka}, 11,30,3 \mathrm{bg}, 14 \mathrm{a}, 14 \mathrm{~b}, 15,23,28$ & MFRHQQ & 000011001011100 & 13 \\
\hline UR 11-3 & $1,2 \mathrm{a}, 2 \mathrm{c}, 3,17,3 \mathrm{bg}, 10,14 \mathrm{a}, 14 \mathrm{~b}, 15,18,20,23,28$ & TBDKTQ & 000011001011000 & 11 \\
\hline UR $15-3$ & $1,2 \mathrm{a}, 2 \mathrm{c}, 3,17,3 \mathrm{bg}, 10,14 \mathrm{a}, 14 \mathrm{~b}, 15,18,20,23,28$ & TBDKTQ & 000011001011100 & 13 \\
\hline SF 9-1 & $2 \mathrm{c}, 3, \mathrm{~B}, 3 \mathrm{bg}, 10,14 \mathrm{a}, 14 \mathrm{~b}, 20$ & FBBTMB & 000110000011101 & 15 \\
\hline SF $1-2$ & $2 \mathrm{c}, 3,3 \mathrm{ka}, 30, \mathrm{~B}, 14 \mathrm{a}, 14 \mathrm{~b}, 18$ & FBMMNB & 111100011001100 & 77 \\
\hline SF $1-1$ & $2 \mathrm{a}, 2 \mathrm{c}, 3,3 \mathrm{ka}, 30, \mathrm{~B}, 10,14 \mathrm{a}, 14 \mathrm{~b}, 20$ & KBMPMB & 011100011001101 & 26 \\
\hline SF $5-2$ & $2 \mathrm{a}, 2 \mathrm{c}, 3,24, \mathrm{~B}, 10,14 \mathrm{a}, 14 \mathrm{~b}, 20$ & KDBPMB & 111010010011000 & 74 \\
\hline SF 2-1 & $1,2 \mathrm{a}, 3,24,3 \mathrm{ka}, 11,30, \mathrm{~B}, 10,14 \mathrm{a}, 14 \mathrm{~b}, 20,28$ & PDRPMG & 000010010001101 & 8 \\
\hline SF 7-1 & $1,2 \mathrm{a}, 2 \mathrm{c}, 24, \mathrm{~B}, 14 \mathrm{a}, 14 \mathrm{~b}, 15,20,23,28$ & SDBMRQ & 000010010011101 & 9 \\
\hline SF 6-1 & $1,2 \mathrm{a}, 2 \mathrm{c}, 24, \mathrm{~B}, 10,14 \mathrm{a}, 14 \mathrm{~b}, 15,20,28$ & SDBPRG & 011110001011001 & 28 \\
\hline SF 3-1 & $1,2 \mathrm{a}, 2 \mathrm{c}, 24,17, \mathrm{~B}, 10,14 \mathrm{a}, 14 \mathrm{~b}, 15,20,23,28$ & SDDPRQ & 111010010011101 & 75 \\
\hline GB 90-11-1 & $\mathrm{B}, 10,14 \mathrm{~b}, 23$ & BBBNLL & 100110111101100 & 54 \\
\hline GB 76-1-2 & $\mathrm{B}, 10,14 \mathrm{~b}, 20,23$ & BBBNML & 101110111101110 & 70 \\
\hline GB 90-26-2 & $11, \mathrm{~B}, 14 \mathrm{~b}, 23$ & BBGLLL & 101110111101111 & 71 \\
\hline GB 94-1-1 & $3,26,3 \mathrm{ka}, 17,30, \mathrm{~B}, 3 \mathrm{bg}, 14 \mathrm{~b}, 15,23$ & CCPQQL & 101010011011100 & 63 \\
\hline GB 94-1-2 & $3,26,3 \mathrm{ka}, 17,30, \mathrm{~B}, 3 \mathrm{bg}, 14 \mathrm{~b}, 15,20,23$ & CCPQRL & 101010011001111 & 61 \\
\hline GB 93-1-2 & $2 \mathrm{c}, \mathrm{B}, 10,14 \mathrm{~b}, 23$ & DBBNLL & 100110011001100 & 49 \\
\hline GB 82-1-2 & $2 \mathrm{c}, \mathrm{B}, 10,14 \mathrm{~b}, 20,23$ & DBBNML & 100110011001111 & 51 \\
\hline GB $83-1-2$ & $2 \mathrm{c}, \mathrm{B}, 10,14 \mathrm{~b}, 18,23$ & DBBNNL & 101110011001000 & 68 \\
\hline GB 81-5-1 & $2 \mathrm{c}, 11, \mathrm{~B}, 14 \mathrm{~b}, 23$ & DBGLLL & 100110111101111 & 56 \\
\hline GB 90-10-2 & $2 \mathrm{c}, 11, \mathrm{~B}, 14 \mathrm{a}, 14 \mathrm{~b}, 20,23$ & DBGMML & 100110110111100 & 54 \\
\hline GB 80-1-1 & $2 \mathrm{c}, 11, \mathrm{~B}, 10,14 \mathrm{~b}, 23$ & DBGNLL & 100110111101100 & 54 \\
\hline GB 90-12-2 & $2 \mathrm{c}, 11, \mathrm{~B}, 10,14 \mathrm{~b}, 23$ & DBGNLL & 100110111101111 & 56 \\
\hline GB 81-2-1 & $2 \mathrm{c}, 11, \mathrm{~B}, 10,14 \mathrm{~b}, 23$ & DBGNLL & 101110111101111 & 72 \\
\hline GB 81-5-1 & $2 \mathrm{c}, 11, \mathrm{~B}, 10,14 \mathrm{~b}, 20,23$ & DBGNML & 100110111101100 & 54 \\
\hline GB $85-31-2$ & $2 \mathrm{c}, 26,11, \mathrm{~B}, 10,14 \mathrm{~b}, 20,23$ & DCGNML & 100110111101101 & 55 \\
\hline GB 93-1-1 & $2 \mathrm{c}, 3,3 \mathrm{ka}, 30, \mathrm{~B}, 3 \mathrm{bg}, 10,14 \mathrm{a}, 14 \mathrm{~b}, 23$ & FBMTLL & 101110011011100 & 69 \\
\hline
\end{tabular}


the U.S. Department of Agriculture Cereal Disease Laboratory in St. Paul, MN. Isolates from Canada were from the 1995 and 1996 annual virulence surveys. All collections were increased on seedling plants of the susceptible cv. Little Club in $10-\mathrm{cm}$ pots that had been treated with maleic hydrazide to enhance spore production. A plastic cylinder was placed over each pot to prevent cross-contamination. To ensure purity of the cultures, single uredinia from each collection were isolated and increased on 'Little Club'. The single-uredinial isolates were stored under vacuum at $4^{\circ} \mathrm{C}$.

Determination of virulence phenotypes. All single-uredinial isolates were tested for virulence on seedling plants of Thatcher wheat lines that are near-isogenic for leaf rust resistance genes: Lr1, 6003; Lr2a, RL 6000; Lr2c, RL 6047; Lr3, RL 6002; Lr3bg, RL 6042; Lr3ka, RL 6007; Lr9, RL 6010; Lr10, RL 6004; Lr11, RL 6053; Lr14a, RL 6013; Lr14b, RL 6006; Lr15, RL 6052; Lr16, RL 6005; Lr17, RL 6008; Lr18, RL 6009; Lr20, RL 6092; Lr23, RL 6012; Lr24, RL 6064; Lr26, RL 6078; Lr28, RL 6079; Lr30, RL 6049; and $L r B$, RL 6051. Thatcher RL 6161 was included as a susceptible control. Inoculation, incubation, and greenhouse conditions were as previously described (12). Infection types 0 to $2^{+}$ were classified as avirulent, and infection types 3 to 4 were classified as virulent. Virulence phenotypes of the isolates were described with an expanded version of the Prt nomenclature (22). The first three letters correspond to the avirulent/virulent infection types on the three sets of four differentials in the Prt nomenclature (22): $L r 1, L r 2 a, L r 2 c$, and $L r 3 ; L r 9, L r 16, L r 24$, and $L r 26$; and $L r 3 k a$, $L r 11, L r 17$, and $L r 30$, respectively. The fourth letter describes avirulent or virulent infection types on differentials with genes $\operatorname{LrB}$, $\mathrm{Lr3bg}, \mathrm{Lr} 10$, and $\mathrm{Lr} 14 \mathrm{a}$. The fifth letter describes infection types on differentials with genes $L r 14 b, L r 15, L r 18$, and $L r 20$. The sixth letter describes infection types on differentials with genes $L r 23$ and Lr28, with two imaginary differentials always set to avirulent.

Determination of molecular phenotypes. Urediniospores of the $P$. triticina isolates were increased on seedlings of 'Little Club' wheat and germinated as previously described (21). DNA extraction, RAPD-polymerase chain reaction conditions, and running and scoring of gels were as previously described $(18,21)$. Arbitrary 10base primers $402,450,489,517,519,521,538,556$, and 889 from the University of British Columbia Biotechnology Laboratory (Vancouver, British Columbia, Canada); OPR2 from Operon Technologies (Alameda, CA); and the simple sequence repeat primer CRC 12 synthesized at the Cereal Research Centre (Winnipeg, Manitoba, Canada) were used in this study. Sequences and photographs of amplification products for all the primers have been published

A

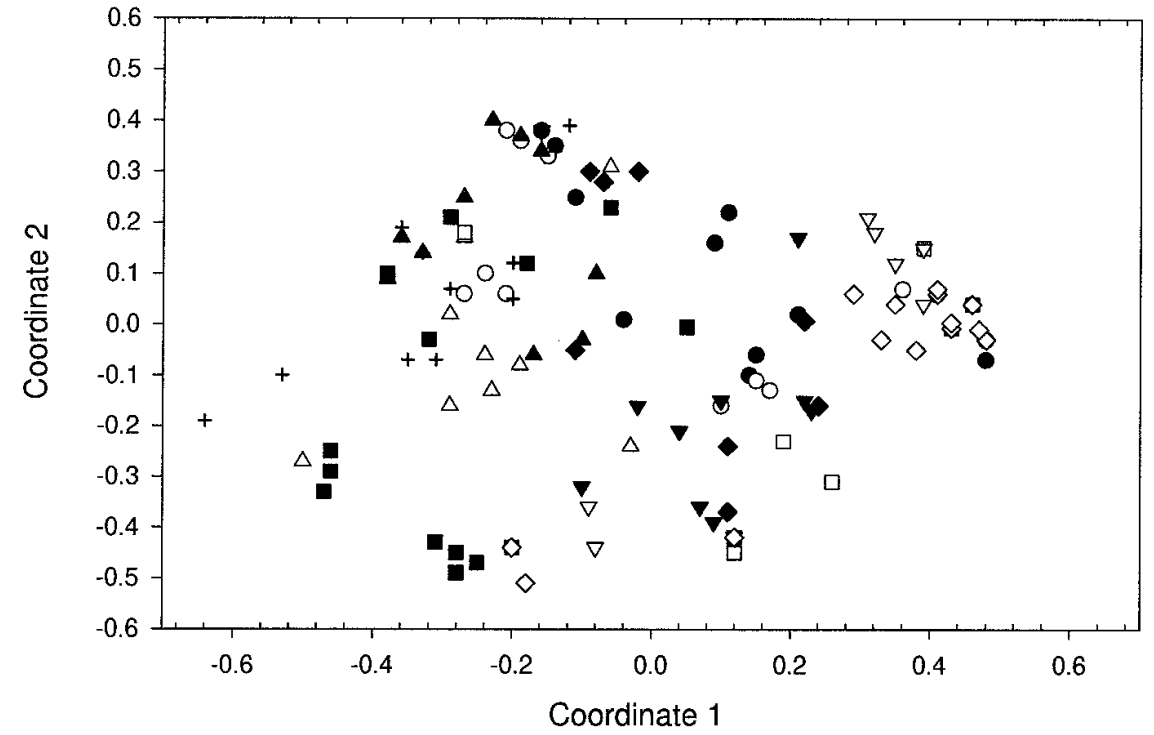

- Australia-New Zealand O Nepal-Pakistan - Canada 1

$\triangle$ Canada 2

Coordinate 1

- Central Europe

$\square$ Spain

$\checkmark$ Israel

$\nabla$ italy

+ South America

B

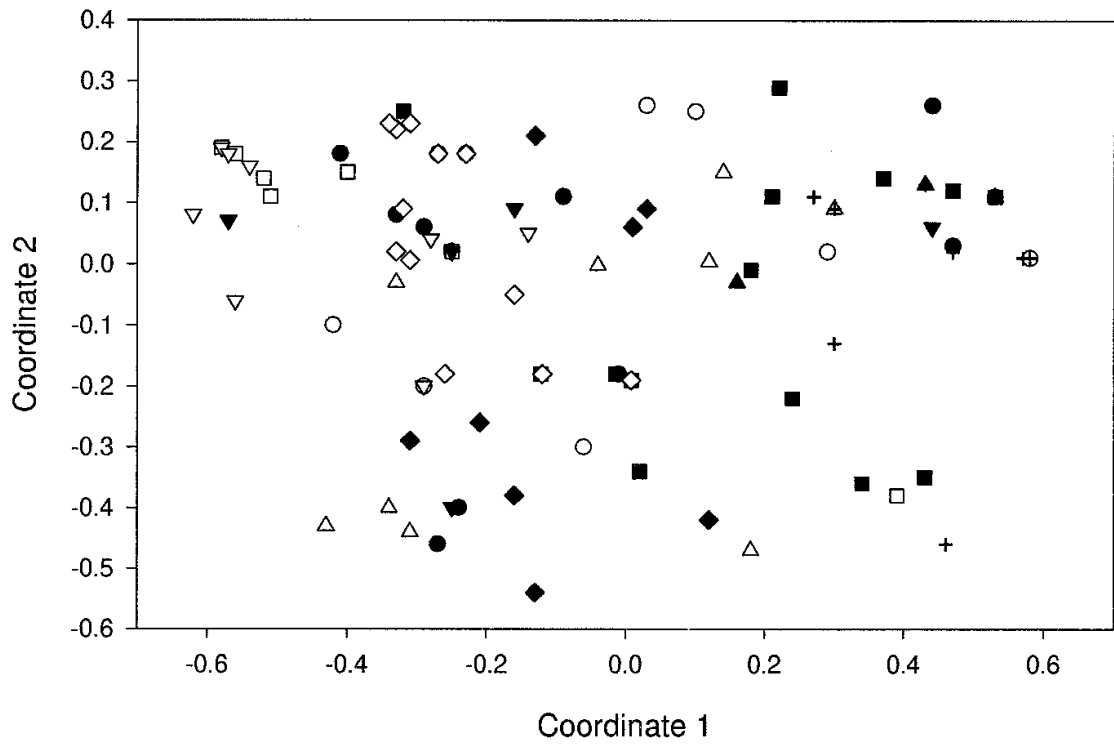

- South Africa

$\diamond$ Britain

Coordinate 1

Fig. 1. Two-dimensional principal coordinate plot of 131 Puccinia triticina isolates. A, Principal coordinates based on virulence differences to 22 Thatcher near-isogenic lines. B, Principal coordinates based on differences in 15-digit random amplified polymorphic DNA phenotypes. 
previously $(18,21)$. For all primers, only the major polymorphic bands were considered. All isolates were tested at least twice with each primer to confirm the DNA banding pattern. Primers 519 and 489 generated four and two polymorphic bands, respectively, that were scored independently. All other primers generated a single polymorphic band that was scored as either present or absent. A 15-digit binary number based on the presence or absence of polymorphic DNA bands was used to describe the RAPD phenotype of each isolate. Each binary number was assigned a RAPD phenotype number after being sorted in ascending order. The polymorphism generated by these primers was previously shown to be genetically independent of any virulence phenotypes (21).

Data analysis. Only isolates that had a unique virulence-RAPD phenotype from each country were included in the analysis. There were no clones from the same country included. Generally, one to two isolates of each virulence phenotype from each country were tested for RAPD phenotype. Previous studies indicated there was usually no or little RAPD variation between isolates with the same virulence phenotype. If isolates with the same virulence phenotype had different RAPD phenotypes, then both isolates were included in the data analysis. If isolates had the same virulence and RAPD phenotypes, then only one isolate was included. A total of 131 isolates was included in the final data analysis. Collections from Slovakia, Germany, and Hungary were grouped together to form the central Europe collection based on previous survey data $(3,24)$, which indicated that isolates with similar or identical virulence phenotypes were collected from these countries. Isolates from Uruguay and Brazil were grouped together as the South America collection, since these countries are in the same epidemiological zone $(9,26)$. Collections from Australia and New Zealand were grouped together, since virulence phenotypes in Australia migrated to New Zealand $(23,25)$. Isolates from Pakistan and Nepal were grouped together, since similar or identical virulence phenotypes were previously found in the two countries (11). Collections from Great Britain, Israel, Italy, Spain, and South Africa were considered separately. Isolates from western Canada were designated as the Canada- 1 collection, and isolates from eastern Canada were designated as the Canada- 2 collection. A modified analysis of variance based on a matrix of squared-distances among all pairs of phenotypes and multiple permutations-randomizations of the data set (8) was used to partition virulence and RAPD variation within and between the different $P$. triticina collections. This analysis of molecular variation was originally adapted for partitioning molecular variation in collections of nonrecombinant human mitochondrial genomes. The analysis of variance produced estimates of variance components that reflect the phenotypic diversity at different hierarchical levels (10).

The average number of virulence differences within and between pairs of isolates in the different collections was determined using the simple distance coefficient: $d / n$, in which $d=$ number of virulence differences between paired isolates; and $n=$ total number of virulences.

The average RAPD difference between pairs of isolates in the different collections was determined using the complement of the
Dice coefficient (28): $1-(2 a / 2 a+b+c)$, in which $a=$ bands present in isolates $i$ and $j ; b=$ band present in isolate $i$, absent in isolate $j$; and $c=$ band present in isolate $j$, absent in isolate $i$.

Separate two-dimensional principal coordinate plots of the individual isolates based on virulence and RAPD phenotypes were developed using NTSYS-pc version 1.8 (Exeter Software, Setauket, NY). The two-dimensional eigenvectors for individual isolates were derived by transforming the symmetric dissimilarity matrices with DCENTER. The double-centered matrices were then used with EIGEN to calculate the eigenvectors.

The matrices of the average virulence and RAPD differences between collections were used to construct dendrograms using SAHN clustering in the UPGMA program in NTSYS-pc. COPH was used to derive cophenetic value matrices from the dendrograms, which were correlated with the original dissimilarity matrices. Three-dimensional principal coordinate plots of the virulence and RAPD differences between collections were constructed using the DCENTER and EIGEN programs. A two-dimensional dendrogram and a threedimensional principal coordinate plot of RAPD differences between isolates in virulence groups defined by avirulent/virulent infection types on the Thatcher lines with $L r 1, L r 2 a, L r 2 c$, and $L r 3$ were also constructed. Associations between virulences to specific $L r$ genes and polymorphic DNA bands were determined using Fisher's exact test (29) in PROC FREQ of SAS (SAS Institute, Cary, NC).

\section{RESULTS}

There were 105 virulence phenotypes and 82 RAPD phenotypes (Table 1) among the 131 P. triticina isolates examined in this study. Isolates from some collections were identical for RAPD phenotype, although they differed for virulence phenotype. RAPD phenotype 13 occurred in eight virulence phenotypes in the Canada-1 collection; RAPD phenotype 45 occurred in six virulence phenotypes in the Israel collection; and RAPD phenotypes 11 and 13 each occurred in four virulence phenotypes in the Brazil-Uruguay collection. The other collections had nearly equal numbers of RAPD phenotypes and isolates.

RAPD phenotypes 13 and 45 were the most common RAPD phenotypes (Table 1). RAPD phenotype 13 was found in 14 isolates and was a common phenotype in the Brazil-Uruguay and Canada-1 collections. One isolate of RAPD phenotype 13 was also found in the Hungary and New Zealand collections. RAPD phenotype 45 (nine isolates in total) was a common phenotype in the isolates from Israel and was also found in one isolate each from the New Zealand and Pakistan collections.

The most common virulence phenotype was LCGFSQ, which occurred in a total of four isolates from Uruguay, Great Britain, and New Zealand. The LCGFSQ isolates from Uruguay and New Zealand had RAPD phenotype 11. Other virulence phenotypes were also widely distributed: BBBNLL occurred in single isolates from Britain, Israel, and Germany; and TBDKTQ occurred in one isolate from Hungary and two isolates from Uruguay. One of the

TABLE 2. Average difference of virulence (simple distance coefficient [top diagonal]) and difference of random amplified polymorphic DNA (1 - Dice coefficient [bottom diagonal]) within and between collections of Puccinia triticina isolates

\begin{tabular}{|c|c|c|c|c|c|c|c|c|c|c|c|c|}
\hline & $\begin{array}{c}\text { Australia- } \\
\text { New Zealand }\end{array}$ & $\begin{array}{c}\text { Pakistan- } \\
\text { Nepal }\end{array}$ & Canada-1 & Canada-2 & $\begin{array}{l}\text { Central } \\
\text { Europe }\end{array}$ & Spain & Israel & Italy & $\begin{array}{l}\text { Brazil- } \\
\text { Uruguay }\end{array}$ & $\begin{array}{l}\text { South } \\
\text { Africa }\end{array}$ & $\begin{array}{l}\text { Great } \\
\text { Britain }\end{array}$ & $\begin{array}{c}\text { Difference } \\
\text { within }\end{array}$ \\
\hline Australia-New Zealand & & 0.30 & 0.34 & 0.39 & 0.44 & 0.27 & 0.31 & 0.26 & 0.41 & 0.30 & 0.27 & 0.25 \\
\hline Pakistan-Nepal & 0.35 & & 0.34 & 0.39 & 0.42 & 0.33 & 0.34 & 0.33 & 0.38 & 0.34 & 0.40 & 0.30 \\
\hline Canada-2 & 0.42 & 0.41 & 0.44 & & 0.39 & 0.41 & 0.41 & 0.41 & 0.37 & 0.39 & 0.44 & 0.33 \\
\hline Central Europe & 0.42 & 0.35 & 0.27 & 0.44 & & 0.41 & 0.42 & 0.42 & 0.43 & 0.47 & 0.44 & 0.38 \\
\hline Spain & 0.41 & 0.39 & 0.53 & 0.42 & 0.50 & & 0.31 & 0.23 & 0.46 & 0.35 & 0.26 & 0.26 \\
\hline Israel & 0.35 & 0.35 & 0.44 & 0.34 & 0.44 & 0.30 & & 0.33 & 0.43 & 0.40 & 0.31 & 0.28 \\
\hline South Africa & 0.41 & 0.37 & 0.45 & 0.42 & 0.40 & 0.41 & 0.40 & 0.38 & 0.46 & & 0.38 & 0.29 \\
\hline Great Britain & 0.38 & 0.32 & 0.45 & 0.40 & 0.41 & 0.33 & 0.33 & 0.30 & 0.50 & 0.39 & & 0.20 \\
\hline Difference within & 0.38 & 0.32 & 0.07 & 0.33 & 0.33 & 0.33 & 0.24 & 0.18 & 0.16 & 0.35 & 0.18 & \\
\hline
\end{tabular}


TBDKTQ isolates from Uruguay and the TBDKTQ isolate from Hungary had RAPD phenotype 13. Phenotype DBBDML occurred in two isolates from Spain and one isolate from Italy. One of the DBBDML isolates from Spain and the DBBDML isolate from Italy had RAPD phenotype 40. Other virulence phenotypes were also found in more than one collection; however, these isolates had different RAPD phenotypes.

A two-dimensional principal coordinate plot of the individual isolates based on their virulence differences (simple distance coef-

\section{Dissimilarity}
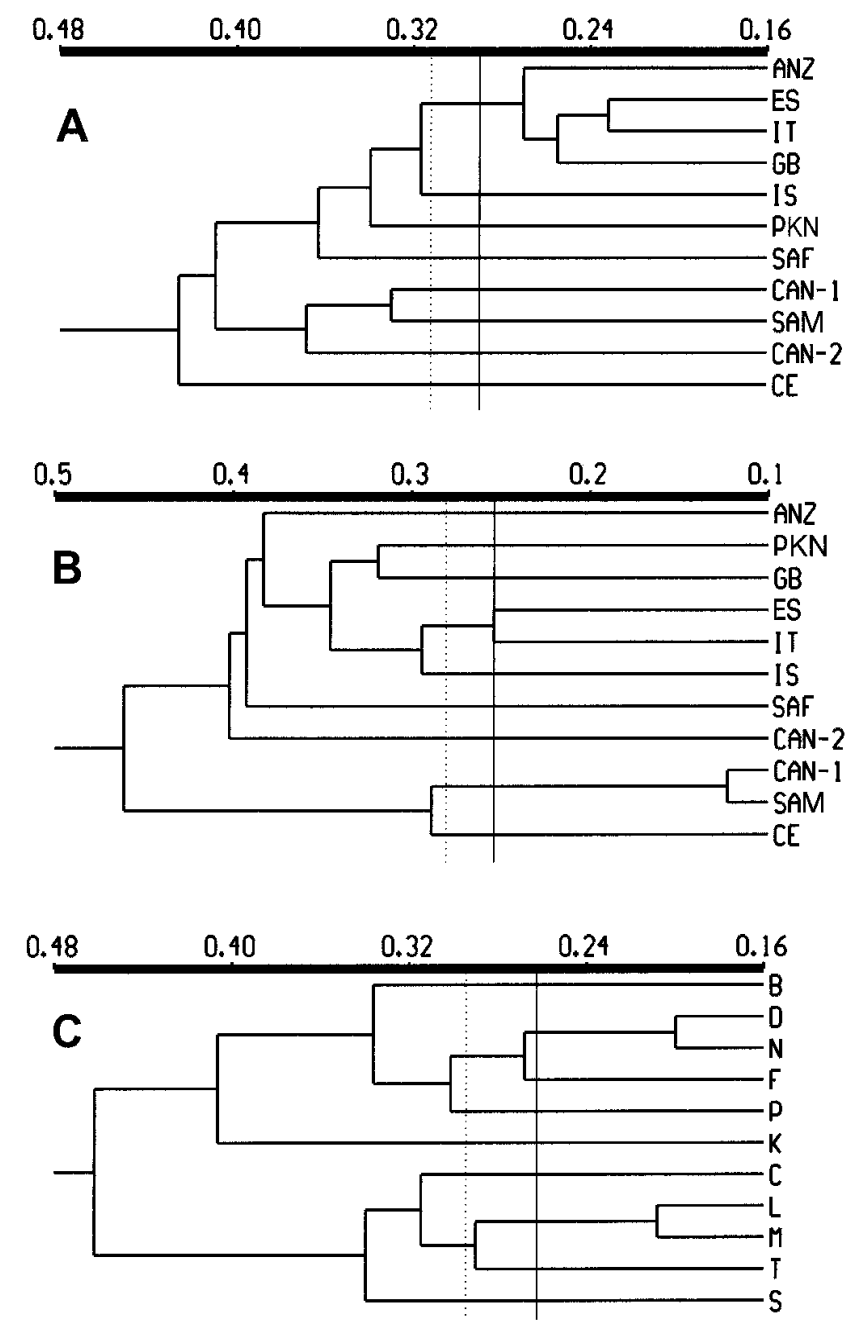

Fig. 2. A and B, Dendrograms of 131 Puccinia triticina isolates grouped into 11 collections. The UPGMA method in the SAHN program of NTSYS-pc version 1.8 was used. The solid vertical line indicates the average variation within collections, and the dotted line indicates the upper 95\% confidence limit of the average within-group variation. ANZ = Australia-New Zealand, $\mathrm{PKN}=$ Pakistan-Nepal, GB $=$ Great Britain, ES $=$ Spain, IT $=$ Italy, IS = Israel, $\mathrm{SAF}=$ South Africa, $\mathrm{CAN}-2=$ eastern Canada, $\mathrm{CAN}-1=$ western Canada, SAM = South America, and CE = central Europe. A, Dendrogram based on virulence to 22 Thatcher near-isogenic lines. Dissimilarity between $P$. triticina collections was measured using the simple distance coefficient. B, Dendrogram based on 15-digit random amplified polymorphic DNA (RAPD) phenotypes. Dissimilarity between $P$. triticina collections was measured using the complement of the Dice coefficient (1 - Dice coefficient). C, Dendrogram of RAPD differences within and between sets of isolates grouped according to avirulent/virulent infection types to Thatcher wheat lines with genes $L r 1, L r 2 a, L r 2 c$, and $L r 3$ (22). B = Avirulent to all four genes; $\mathrm{C}=$ virulent to $L r 3 ; \mathrm{D}=$ virulent to $L r 2 c ; \mathrm{F}=$ virulent to $L r 2 c$ and $L r 3 ; \mathrm{K}=$ virulent to $L r 2 a, L r 2 c$, and $L r 3 ; \mathrm{L}=$ virulent to $L r 1 ; \mathrm{M}=$ virulent to $L r 1$ and $L r 3 ; \mathrm{N}=$ virulent to $L r 1$ and $L r 2 c ; \mathrm{P}=$ virulent to $L r 1, L r 2 c$, and $L r 3 ; \mathrm{S}=$ virulent to $L r 1, L r 2 a$, and $L r 2 c$; and $\mathrm{T}=$ virulent to all four genes. Dissimilarity between $P$. triticina collections was measured using the complement of the Dice coefficient (1 - Dice coefficient).
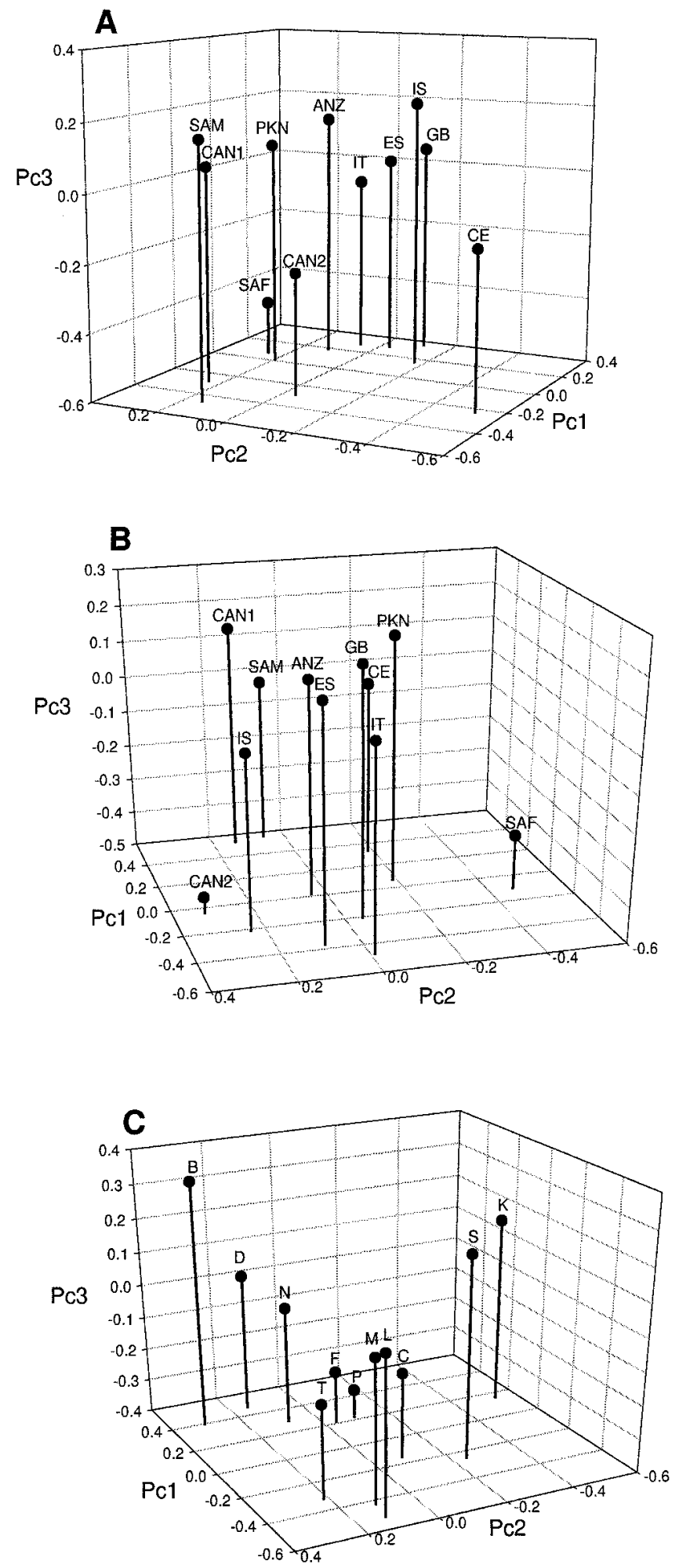

Fig. 3. A and B, Three-dimensional principal coordinates of 131 Puccinia triticina isolates grouped into 11 collections: $\mathrm{ANZ}=$ Australia-New Zealand, $\mathrm{PKN}=$ Pakistan-Nepal, GB = Great Britain, ES = Spain, IT = Italy, IS = Israel, $\mathrm{SF}=$ South Africa, $\mathrm{CA} 2$ = eastern Canada, $\mathrm{CA} 1=$ western Canada, $\mathrm{SAM}=$ South America, and CE = central Europe. A, Principal coordinates based on virulence to 22 Thatcher near-isogenic lines. B, Principal coordinates based on 15-digit random amplified polymorphic DNA (RAPD) phenotypes. C, Principal coordinates of RAPD differences between groups of isolates grouped according to avirulent/virulent infection types to Thatcher wheat lines with genes $L r 1, L r 2 a, L r 2 c$, and $\operatorname{Lr} 3$ (22). B = Avirulent to all four genes; $\mathrm{C}=$ virulent to $L r 3 ; \mathrm{D}=$ virulent to $L r 2 c ; \mathrm{F}=$ virulent to $L r 2 c$ and $L r 3 ; \mathrm{K}=$ virulent to $L r 2 a, L r 2 c$, and $L r 3 ; \mathrm{L}=$ virulent to $L r 1 ; \mathrm{M}=$ virulent to $L r 1$ and $L r 3 ; \mathrm{N}=$ virulent to $L r 1$ and $L r 2 c ; \mathrm{P}=$ virulent to $L r 1, L r 2 c$, and $L r 3 ; \mathrm{S}=$ virulent to $L r 1, L r 2 a$, and $L r 2 c$; and $\mathrm{T}=$ virulent to all four genes. 
ficients converted to eigenvectors) is shown in Figure 1A. On an individual basis, it is difficult to see discrete groupings, as isolates from different collections can be found in more than one area of the plot. However, isolates from the same collection tended to group closer than with isolates from other groups. The first two dimensions accounted for $37 \%$ of the variation.

The 131 isolates were also examined for differences in virulence (simple distance coefficient) within and between the 11 collections (Table 2). Collections from Great Britain and Italy were the least variable for virulence with an average of 0.20 difference, while the collection from central Europe was the most variable at 0.38 . The weighted average virulence difference within all collections was 0.28. In pairs of collections, isolates from Spain and Italy differed the least for virulence with an average of 0.23 , while isolates from South Africa and central Europe and from Great Britain and Brazil-Uruguay differed the most with an average of 0.47. The weighted average virulence distance between all collections was 0.38 . In the modified analysis of variance, differences between collections accounted for $26 \%(P<0.001,10,000$ randomizations $)$ of the total virulence variation. The remaining variation occurred between isolates within collections.

The average virulence distances between collections from Table 2 were also plotted in dendrogram form using the UPGMA procedure (Fig. 2A). Branch points between different collections that were greater than the upper 95\% confidence level of the within-collection mean were considered as significant. Using this criterion, there were eight distinct groups based on virulence polymorphism. Collections from Australia-New Zealand, Spain, Italy, and Great Britain did not differ significantly for virulence. The other seven groups had significant differences in virulence. The correlation of the virulence difference matrix with the cophenetic dendrogram matrix was 0.89 .

The average virulence distances between groups were also plotted in three-dimensional space using principal coordinates (Fig. 3A). Collections from Australia-New Zealand, Spain, Italy, and Britain were fairly close together, while collections from central Europe, South Africa, and Canada-2 were separated from the other groups. The first three dimensions accounted for $44 \%$ of the total variation.

The isolates were also examined for differences in RAPD variation within and between collections. The two-dimensional principal coordinate plot of individual isolates based on differences in RAPD phenotype (Fig. 1B) (1 - Dice coefficient converted to eigenvectors) was more scattered compared with the virulence plot. There was no discrete grouping of isolates; however, isolates from the same collections were generally found in the same area of the plot, even though there was considerable overlap of isolates from different collections. The first two dimensions accounted for $48 \%$ of the variation.

Isolates from Australia-New Zealand had the highest average within-collection RAPD variation of 0.38 (Table 2). The Canada-1 collection had the lowest within-collection RAPD variation of 0.07 . The overall weighted average within-collection RAPD difference was 0.26 . The average RAPD differences between collections ranged from 0.64 for Italy compared with Brazil-Uruguay, and 0.12 for

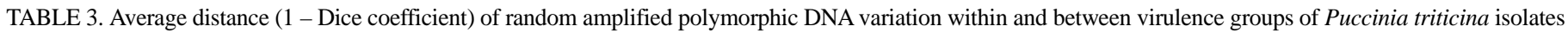

\begin{tabular}{|c|c|c|c|c|c|c|c|c|c|c|c|c|}
\hline & $\mathrm{B} \_$a & $\mathrm{C}_{2}$ & $\mathrm{D}$ & $\mathrm{F}_{-}$ & $\mathrm{K}$ & $\mathrm{L}$ & $\mathrm{M}_{-}$ & $\mathrm{N}_{-}$ & $\mathrm{P}_{-}$ & $\mathrm{S}$ & $\mathrm{T}_{-}$ & No. of isolates \\
\hline $\mathrm{B}$ & $0.33^{b}$ & & & & & & & & & & & 8 \\
\hline $\mathrm{C}$ & $0.47^{\mathrm{c}}$ & 0.28 & & & & & & & & & & 10 \\
\hline D & 0.30 & $\overline{0.45}$ & 0.25 & & & & & & & & & 23 \\
\hline $\mathrm{F}$ & 0.37 & 0.35 & $\overline{0.31}$ & 0.27 & & & & & & & & 12 \\
\hline $\mathrm{K}$ & 0.49 & 0.39 & 0.43 & 0.37 & 0.47 & & & & & & & 2 \\
\hline $\mathrm{L}$ & 0.60 & 0.35 & 0.63 & 0.48 & $\overline{0.54}$ & $\underline{0.18}$ & & & & & & 7 \\
\hline $\mathrm{M}$ & 0.52 & 0.28 & 0.56 & 0.43 & 0.50 & $\overline{0.21}$ & 0.15 & & & & & 17 \\
\hline $\mathrm{N}$ & 0.29 & 0.34 & 0.20 & 0.23 & 0.36 & 0.49 & $\overline{0.42}$ & & & & & 1 \\
\hline $\mathrm{P}$ & 0.39 & 0.36 & 0.34 & 0.28 & 0.38 & 0.50 & 0.46 & 0.30 & 0.29 & & & 20 \\
\hline $\mathrm{S}$ & 0.54 & 0.35 & 0.53 & 0.40 & 0.41 & 0.32 & 0.33 & 0.40 & 0.42 & 0.38 & & 9 \\
\hline $\mathrm{T}_{-}$ & 0.50 & 0.31 & 0.50 & 0.39 & 0.50 & 0.33 & 0.25 & 0.37 & 0.42 & $\overline{0.37}$ & $\underline{0.30}$ & 22 \\
\hline
\end{tabular}

a Virulence groups determined by infection type on Thatcher lines with $\operatorname{Lr} 1, \operatorname{Lr} 2 a, \operatorname{Lr} 2 c$, and $\operatorname{Lr} 3$ (22).

b Similarity within virulence group (underlined).

c Similarity between virulence groups.

TABLE 4. Associations as measured by Fisher's exact test between pairs of virulence to specific leaf rust resistance genes in an international collection of Puccinia triticina isolates

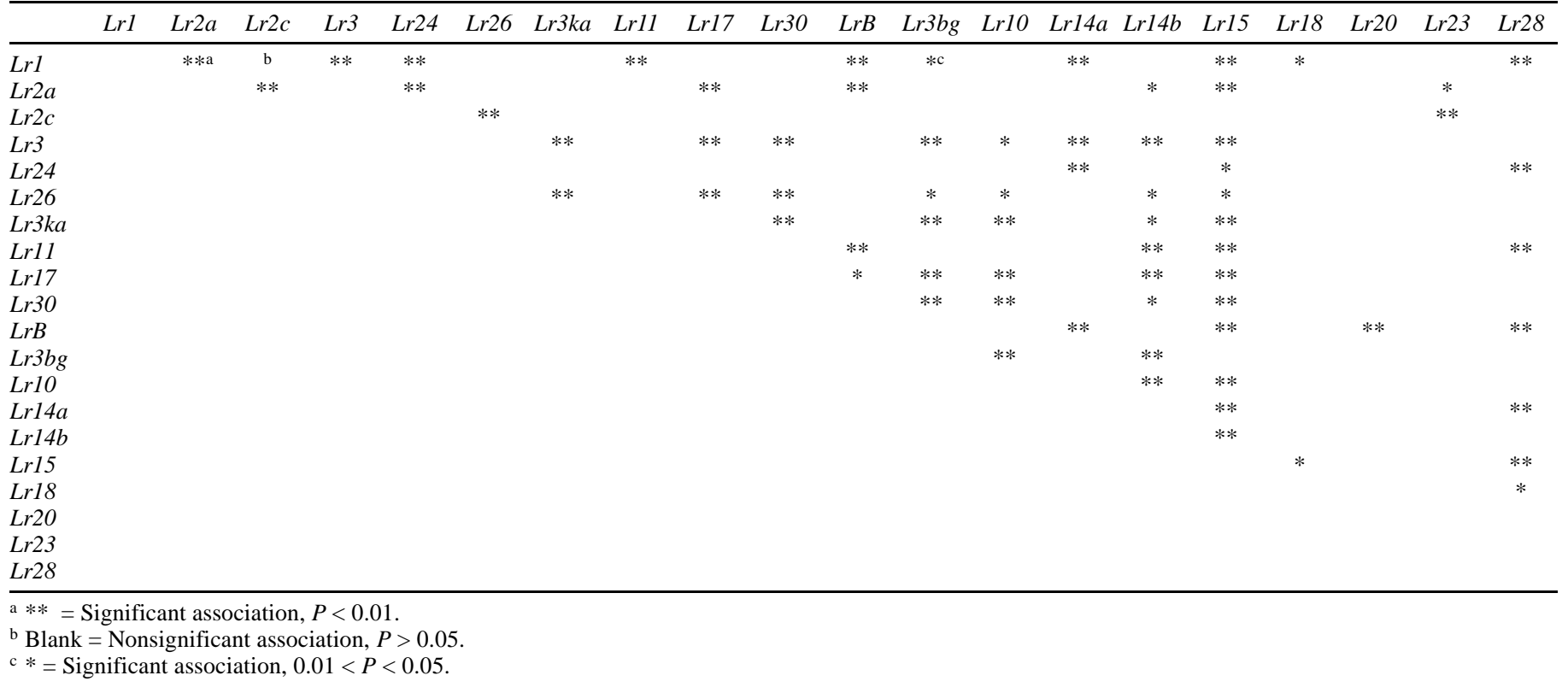


Canada-1 compared with Brazil-Uruguay. The overall weighted average RAPD difference between collections was 0.39 . The modified analysis of variance indicated that $36 \%$ of the RAPD variation $(P<$ $0.001,10,000$ randomizations) could be attributed to differences between collections, with the balance due to variation between isolates within collections.

With UPGMA clustering, there were nine groups based on the average RAPD differences between and within collections (Fig. 2B). Isolates from Spain and Italy grouped together, as did isolates from Brazil-Uruguay (South America) and Canada-1. The matrix of RAPD differences had a 0.79 correlation with the cophenetic dendrogram matrix. The virulence and RAPD distance matrices used to construct the dendrograms in Figure 2A and B had a correlation of 0.49 . In a three-dimensional principal coordinate plot, the Canada-2 and South Africa collections were the most distant from the other collections (Fig. 3B). The remaining collections were closer together in three-dimensional space. The first three dimensions accounted for $52 \%$ of the variation.

To determine if there was a relationship between virulence phenotypes and RAPD phenotypes, the 131 isolates were grouped according to virulence on the four differential Thatcher lines with resistance genes $L r 1, L r 2 a, L r 2 c$, and $L r 3$. Differential lines with these four genes broadly describe major virulence groups of $P$. triticina and were used for many years as the differentials in the Unified Numeration nomenclature (4). Eleven virulence groups were distinguished on the basis of avirulent/virulent infection types to these four differential lines (Table 3). The weighted average RAPD difference among isolates within virulence groups was 0.26 and the weighted average RAPD distance between virulence groups was 0.40 . The D (virulent to $L r 2 c$ ) and $\mathrm{L}$ (virulent to $L r l$ ) groups had the largest average RAPD distance with 0.63 . The L group also had an average RAPD distance of 0.60 with the B (avirulent to all four differentials) group of isolates. The smallest average RAPD distances between groups were 0.20 between the $\mathrm{D}$ and $\mathrm{N}$ (virulent to $L r l, L r 2 c$ ) groups and 0.21 between the M (virulent to $L r l$, $L r 3$ ) and L groups.

The RAPD distances between virulence groups were also plotted as a dendrogram (UPGMA clustering) in Figure 2C. The matrix of RAPD differences between groups had a 0.79 correlation with the cophenetic matrix derived from the dendrogram. There were seven virulence groups that had branch points greater than the upper $95 \%$ confidence level of the average within-RAPD group distance. Isolates in the $\mathrm{D}, \mathrm{N}$, and $\mathrm{F}$ (virulent to $L r 1, L r 2 c$, and $L r 3$ ) virulence groups were not significantly different for RAPD varia- tion. The L, M, and T (virulent to $L r 1, L r 2 a, L r 2 c$, and $L r 3$ ) phenotypes were also grouped together. The $\mathrm{B}, \mathrm{K}$ (virulent to $\operatorname{Lr} 2 a$, $L r 2 c$, and $L r 3$ ), $\mathrm{C}$ (virulent to $L r 3$ ), and $\mathrm{S}$ (virulent to $L r l, L r 2 a$, and $L r 2 c$ ) phenotypes formed individual groups. At $40 \%$ dissimilarity, there were two major clusters: the B, D, N, F, P, and $\mathrm{K}$ phenotypes grouped together, and the $\mathrm{C}, \mathrm{L}, \mathrm{M}, \mathrm{T}$, and $\mathrm{S}$ phenotypes grouped together in a second cluster. The $\mathrm{D}, \mathrm{N}, \mathrm{F}$, and $\mathrm{P}$ isolates in the first major cluster are all avirulent to $L r 2 a$ and virulent to $L r 2 c$, while in the second major cluster, all isolates were either avirulent or virulent to both $L r 2 a$ and $L r 2 c$.

Similar relationships were seen in three-dimensional principal coordinate representation of RAPD distance between virulence groups (Fig. 3C). The M, L, and T groups were close together, as were the $\mathrm{F}$ and $\mathrm{P}$ groups. The other virulence groups were more separated for RAPD distance. The first three dimensions accounted for $54 \%$ of the variation.

The 131 isolates were also tested for nonrandom associations between virulences, between RAPD markers, and between virulences and RAPD markers. Virulences to genes $\operatorname{Lr} 9$ and $\operatorname{Lr} 16$ were not included, since few or no isolates virulent to these genes were analyzed. Of the 190 virulence pairs that were considered, $69(36 \%)$ were significantly associated $(P<0.05)$ as determined by Fisher's exact test (Table 4). Virulence to $L r 15$ was associated with 15 other virulences, and virulences to $L r l$ and $L r 3$ were associated with 10 and 9 virulences, respectively. Virulence to $L r 23$ was associated with only two other virulences.

All polymorphic DNA bands except $889,0.7 \mathrm{~kb}$, were tested for association. Of the 91 pairs of DNA bands that were considered, 48 pairs $(54 \%)$ were significantly associated $(P<0.05)$ according to Fisher's exact test (Table 5). Bands 402, $1.5 \mathrm{~kb} ; 517,0.6 \mathrm{~kb}$; 519, $2.2 \mathrm{~kb} ; 519,0.8 \mathrm{~kb} ; 538,0.9 \mathrm{~kb}$; and 556, $1.3 \mathrm{~kb}$, were associated with either 10 or 9 other bands. Bands 450, $1.0 \mathrm{~kb}$; 489, $1.0 \mathrm{~kb}$; and OPR2, $1.3 \mathrm{~kb}$, were relatively randomly distributed in the overall collection.

Of 280 virulence-DNA band pairs, $111(40 \%)$ were significantly associated $(P<0.05)$ according to Fisher's exact test (Table 6). Virulences to $\operatorname{Lr} 1, \operatorname{Lr} 3, \operatorname{LrB}, \operatorname{Lr} 15$, and $\operatorname{Lr} 28$ were associated with $10,9,9,10$, and 11 polymorphic DNA bands, respectively. Bands 402, $1.5 \mathrm{~kb} ; 517,0.6 \mathrm{~kb} ; 519,2.2 \mathrm{~kb} ; 519,1.0 \mathrm{~kb}$; and 556, $1.3 \mathrm{~kb}$, were associated with $13,15,11,12$, and 11 virulences, respectively. Virulences to $\operatorname{Lr} 10, \operatorname{Lr} 20$, and $L r 23$ were associated with only two DNA bands each. DNA bands 450, $1.0 \mathrm{~kb}$; 489, $1.0 \mathrm{~kb}$; and OPR2, $1.3 \mathrm{~kb}$, were associated with only one, one, and two virulences, respectively.

TABLE 5. Associations as measured by Fisher's exact test between pairs of randomly amplified polymorphic DNA bands generated by arbitrary DNA primers in an international collection of Puccinia triticina isolates

\begin{tabular}{|c|c|c|c|c|c|c|c|c|c|c|c|c|c|c|}
\hline \multirow[b]{2}{*}{ Primer $^{\mathrm{a} / \mathrm{band}} \mathrm{d}^{\mathrm{b}}$} & \multicolumn{14}{|c|}{ Primer $^{\mathrm{a}} / \mathrm{band}^{\mathrm{b}}$} \\
\hline & $402 / 1.5$ & $450 / 1.0$ & $489 / 2.0$ & $489 / 1.0$ & $517 / 0.6$ & $519 / 2.2$ & $519 / 1.3$ & $519 / 1.0$ & $519 / 0.8$ & $521 / 0.4$ & $538 / 0.9$ & $556 / 1.3$ & OPR2/1.3 & CRC $12 / 1.3$ \\
\hline $402 / 1.5$ & & $\mathrm{c}$ & $* \mathrm{~d}$ & $*$ & $* * \mathrm{e}$ & $* *$ & $*$ & $* *$ & $* *$ & $* *$ & $* *$ & $* *$ & & \\
\hline $450 / 1.0$ & & & & $* *$ & & & & & & & & $*$ & & \\
\hline $\begin{array}{l}517 / 0.6 \\
517 / 0\end{array}$ & & & & & & $* *$ & $* *$ & $* *$ & $* *$ & $* *$ & $* *$ & $* *$ & & $*$ \\
\hline $519 / 2.2$ & & & & & & & $* *$ & $* *$ & $* *$ & $* *$ & $* *$ & $* *$ & & $*$ \\
\hline $521 / 0.4$ & & & & & & & & & & & $*$ & & & \\
\hline $538 / 0.9$ & & & & & & & & & & & & * & & \\
\hline $556 / 1.3$ & & & & & & & & & & & & & & $* *$ \\
\hline OPR2/1.3 & & & & & & & & & & & & & & \\
\hline CRC $12 / 1.3$ & & & & & & & & & & & & & & \\
\hline
\end{tabular}

a Three-digit numbers indicate primers from University of British Columbia; OPR2 was from Operon Technologies; and CRC 12 was synthesized at the Cereal Research Centre in Winnipeg.

${ }^{\mathrm{b}}$ Fragment size of band in kilobases estimated from molecular weight standards run on the same gel.

${ }^{\mathrm{c}}$ Blank = Nonsignificant association, $P>0.05$.

$\mathrm{d} *=$ Significant association, $0.01<P<0.05$.

e $* *=$ Significant association, $P<0.01$. 


\section{DISCUSSION}

This study indicated that on a worldwide basis collections of $P$. triticina differ for virulence as well as molecular backgrounds. While $P$. triticina isolates from different collections differed for virulence and RAPD phenotypes, there was also variation within collections.

Virulence and RAPD variation between and within worldwide $P$. triticina collections are determined by the genotypes of the isolates that were originally introduced to the different regions (23); by overwintering of leaf rust infections within regions and spread of urediniospores between regions (19); and by mutation and selection of virulent isolates by specific resistance genes on a regional basis $(13,14)$. Epidemiologically isolated collections of $P$. triticina that have similar RAPD backgrounds may have resulted from the introduction to each region of genetically similar isolates from the same origin. Overall, isolates from the central Europe, Canada-1, and the South America collections were more similar for RAPD variation compared with collections from western Europe or Asia. Certain P. triticina groups in North and South America may have had the same origin as the central Europe collection. The Canada-2 collection was closer for RAPD variation to the isolates from the Asia and western Europe collections, which indicated that a number of different $P$. triticina groups may have been introduced to North America.

Selection of $P$. triticina phenotypes by host resistance genes would also have a major effect on differentiation of regional collections. Virulence phenotypes in the central Europe collection commonly had virulence to $L r 3$ and $L r 26$, while collections from Great Britain, Spain, and Italy had lower virulence frequencies to the same genes. Many winter wheats in central Europe have $L r 3$ and Lr26 (2,3). P. triticina collections in central and western Europe may have differentiated for virulence and RAPD phenotypes due to host selection. Park and Felsenstein (24) also found that different virulence phenotypes predominated in central and western Europe. Wheat cultivars with $L r 3, L r 10, L r 14 a, L r 24$, and $L r 26$ have been grown in western Canada and the adjacent Great Plains region of the United States. In eastern Canada, susceptible soft white winter wheats have been the predominant cultivars. The sus- ceptible winter wheats have exerted comparatively little selection pressure, as the predominant $P$. triticina virulence phenotypes have remained unchanged in eastern Canada from 1987 to 1998 (12,15, 16,17). The combination of an overwintering leaf rust population and susceptible host has resulted in a relatively stable population of $P$. triticina virulence phenotypes that are distinct from those in western Canada. Overall, the P. triticina collections from North and South America were more similar for virulence compared with the collections from central Europe, western Europe, and Asia.

The general relationship between virulence phenotype and RAPD polymorphism that was found in isolates from eastern and western Canada was also found in the international collections of $P$. triticina. Previously, Kolmer et al. (18) found that isolates avirulent to $\operatorname{Lr} 2 a$ and virulent to $L r 2 c$ were highly associated with certain RAPD phenotypes and formed a cluster distinct from isolates that were virulent or avirulent to both resistance genes. This association between virulence phenotype and RAPD polymorphism was also found in the current study. Isolates in virulence groups $\mathrm{D}, \mathrm{N}, \mathrm{F}$, and $\mathrm{P}$, which are avirulent to $L r 2 a$ and virulent to $L r 2 c$, formed one cluster in the dendrogram at $30 \%$ dissimilarity, while isolates in virulence groups $\mathrm{C}, \mathrm{L}, \mathrm{M}, \mathrm{T}$, and $\mathrm{S}$, which are avirulent or virulent to both genes, clustered together at $33 \%$ dissimilarity for RAPD variation. Isolates in the $\mathrm{B}$ and $\mathrm{K}$ groups, which are avirulent to both $L r 2 a$ and $L r 2 c$, did not cluster with either of the two other groups. B group isolates are unique since they are avirulent to most of the Thatcher differential lines and distinct for RAPD phenotypes. Only two isolates from South Africa were in the K group for this study. RAPD phenotypes of $K$ group isolates from western Canada were previously found to have similar or identical RAPD phenotypes to the M, T, and L isolates (18).

In the current study, isolates in the $\mathrm{S}$ virulence group had distinct RAPD phenotypes compared with those of the other virulence groups. North American S group isolates, which are avirulent to $L r 3$ and the adult plant resistance gene $L r 22 b$ that is in Thatcher, have previously been shown to be unique for a number of characteristics. $\mathrm{S}$ group isolates were the most common phenotype in eastern and western Canada before 1944. After the introduction of cultivars with $L r 3$ and $L r 22 b$, isolates in the $\mathrm{S}$ virulence group became virtually extinct in collections of $P$. triticina from

TABLE 6. Associations as measured by Fisher's exact test between pairs of randomly amplified polymorphic DNA bands generated by arbitrary DNA primers and virulence to specific leaf rust resistance genes in an international collection of Puccinia triticina isolates

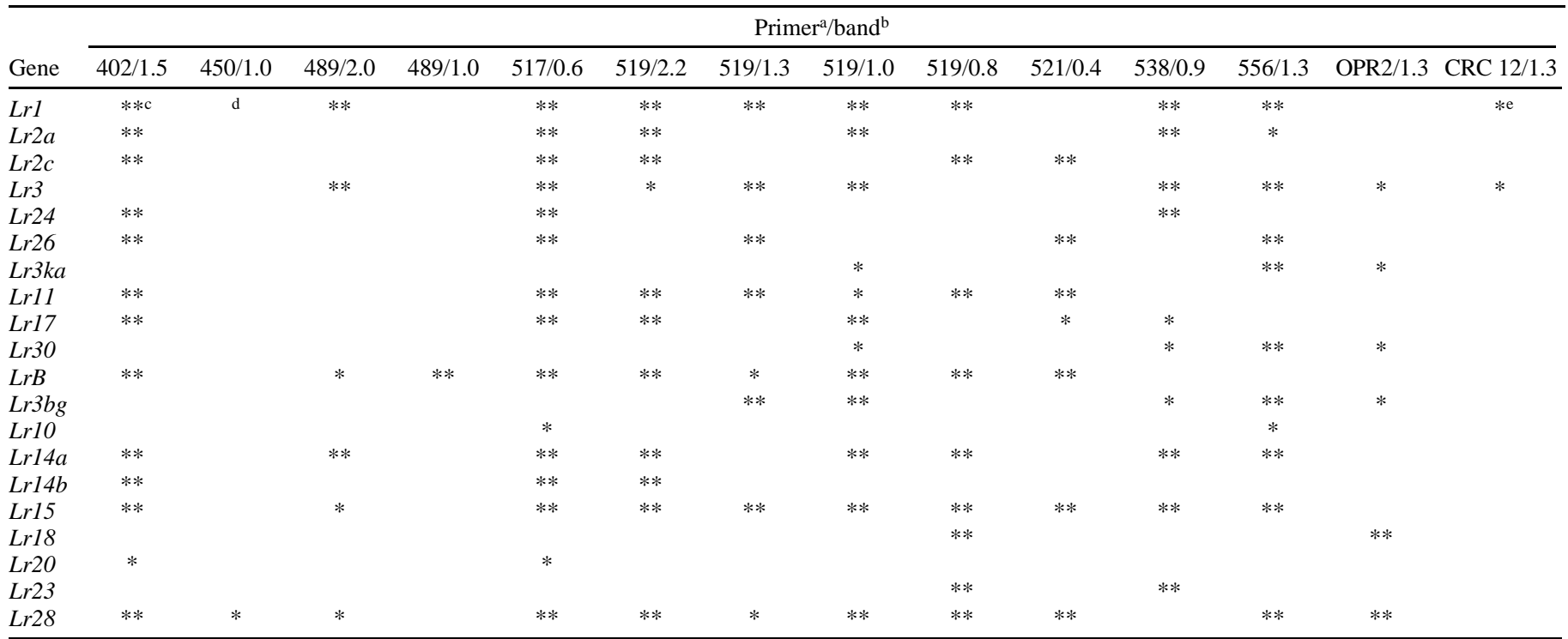

a Three-digit numbers indicate primers from University of British Columbia; OPR2 was from Operon Technologies; and CRC 12 was synthesized at the Cereal Research Centre in Winnipeg.

${ }^{b}$ Fragment size of band in kilobases estimated from molecular weight standards run on the same gel.

c ** = Significant association, $P<0.01$.

${ }^{\mathrm{d}}$ Blank = Nonsignificant association, $P>0.05$.

$\mathrm{e} *$ Significant association, $0.01<P<0.05$. 
wheat in North America (14). These isolates are currently collected in North America from Aegilops cylindrica (goatgrass) in the southern plains and very rarely, if at all, from hexaploid wheat. Burdon and Roelfs (6) showed that $\mathrm{S}$ group isolates had a unique isozyme genotype compared with that of other $P$. triticina isolates in North America. Kolmer et al. (18) determined that a single $\mathrm{S}$ group isolate collected in western Canada in the 1950s had a unique RAPD phenotype compared with that of other isolates from western Canada.

Nonrandom association between virulence and molecular markers would be expected in the P. triticina collections, since these collections reproduce clonally. A greater frequency of the RAPD markers were associated compared with that of the virulences. The RAPD bands 402, $1.5 \mathrm{~kb} ; 517,0.6 \mathrm{~kb} ; 519,2.2 \mathrm{~kb}$; and 556, $1.3 \mathrm{~kb}$, should be useful for population studies, since these were highly associated with other RAPD markers as well as a number of virulences. Liu and Kolmer (21) compared associations between virulences and RAPD markers in an asexual field population from Canada with a sexually derived collection of $P$. triticina. In the asexual population, associations between virulences and RAPD markers were stronger and more frequent compared with those of the sexual collection. The collections used in our study were all believed to have originated from areas where the alternate hosts are neither important epidemiologically nor in the maintenance of genetic variation in this fungus.

Collections of $P$. triticina from diverse regions of the world generally differed for virulence and RAPD phenotypes. In cereal rusts and other plant pathogens, genetic differentiation of populations depends on the relatedness of the original founder populations, movement of individuals within and between populations, and whatever effects mutation and host selection may have on the pathogen population. Currently, one can only speculate on how these factors might contribute to the genetic characteristics of different $P$. triticina populations in North America and worldwide. The virulence surveys that have been conducted annually in Canada since 1931 showed that $P$. triticina populations in eastern and western Canada had the same predominant virulence phenotypes prior to the introduction of resistant wheat cultivars in the 1940s in western Canada. The continual use of resistant wheat cultivars in western Canada and the use of susceptible wheats in eastern Canada would have contributed to the current differentiation of the $P$. triticina populations in these two regions. Differing host selection pressures in the two regions would help to maintain genetically distinct populations. However, migration of $P$. triticina phenotypes from different regions of North America may also occur. Virulence phenotypes commonly found in western Canada often occur at lower frequencies in eastern Canada in the same year $(16,17)$. Urediniospores blown northward from adjacent regions of the United States would also affect genetic diversity in the eastern Canada $P$. triticina population. The relative contributions of the overwintering leaf rust population and the migrant $P$. triticina phenotypes in eastern Canada is unknown. Additional research on virulence and molecular differentiation within the different agro-ecological areas of wheat production in North America and worldwide will be needed to ascertain the relative contributions that overwintering, migration, mutation, and host selection have on genetic identity and diversity of $P$. triticina populations. A more powerful technique for detection of molecular polymorphism, such as amplified fragment length polymorphism, may allow greater discrimination of isolates within and between different virulence groups of the fungus and different geographical regions.

\section{ACKNOWLEDGMENTS}

We thank P. Seto-Goh and C. Sargent for greenhouse and laboratory assistance, S. Woods for SAS programming assistance, R. Sims for graphics, and the various cooperators for supplying collections of Puccinia triticina.

\section{LITERATURE CITED}

1. Anikster, Y., Bushnell, W. R., Eilam, T., Manisterski, J., and Roelfs, A. P. 1997. Puccinia recondita causing leaf rust on cultivated wheats, wild wheats, and rye. Can. J. Bot. 75:2082-2096.

2. Bartos, P., Samborski, D. J., and Dyck, P. L. 1969. Leaf rust resistance of some European varieties of wheat. Can. J. Bot. 47:543-546.

3. Bartos, P., Stuchikova, R., Hanusova, R., and Blazkova, V. 1996. Genes for leaf rust, stem rust and yellow rust resistance in Czech wheat cultivars. Page 239 in: Proc. 9th Eur. and Mediterr. Cereal Rusts and Mildews Conf. G. Kema, R. E. Niks, and R. A. Daamen, eds. Drukkerij Ponsen en Looijen B.V., Wageningen, the Netherlands.

4. Basile, R. 1957. A diagnostic key for the identification of physiologic races of Puccinia rubigo-vera tritici grouped according to a unified numeration scheme. Plant Dis. Rep. 41:508-511.

5. Brown, A. M., and Johnson, T. 1949. Studies on variation in pathogenicity in leaf rust of wheat, Puccinia triticina Erikss. Can. J. Res. Sec. C 27:191-202.

6. Burdon, J. J., and Roelfs, A. P. 1985. Isozyme and virulence variation in asexually reproducing populations of Puccinia graminis and P. recondita on wheat. Phytopathology 75:907-913.

7. D’Oliveira, B. D., and Samborski, D. J. 1966. Aecial stage of Puccinia recondita on Ranunculaceae and Boraginaceae in Portugal. Pages 133-150 in: Proc. 1st Eur. Brown Rust Conf., Cereal Rust Conf. R. C. Macer and M. S. Wolfe, eds. Plant Breeding Institute, Cambridge, United Kingdom.

8. Excoffier, L., Smouse, P. E., and Quattro, J. M. 1992. Analysis of molecular variance inferred from metric distances among DNA haplotypes: Application to human mitochondrial DNA restriction data. Genetics 131: 479-491.

9. German, S. E., and Kolmer, J. A. 1994. Virulence phenotypes of Puccinia recondita f. sp. tritici in Uruguay. Plant Dis. 78:1139-1141.

10. Goodwin, S. B., Allard, R. W., Hardy, S. A., and Webster, R. K. 1992. Hierarchical structure of pathogenic variation among Rhynchosporium secalis collections in Idaho and Oregon. Can. J. Bot. 70:810-817.

11. Huerta-Espino, J. 1992. Analysis of wheat leaf and stem rust on a worldwide basis. Ph.D. thesis. University of Minnesota, St. Paul.

12. Kolmer, J. A. 1988. Physiologic specialization of Puccinia recondita $\mathrm{f}$. sp. tritici in Canada in 1987. Can. J. Plant Pathol. 10:354-358.

13. Kolmer, J. A. 1989. Virulence and race dynamics of Puccinia recondita f. sp. tritici in Canada during 1956-1987. Phytopathology 79:349-356.

14. Kolmer, J. A. 1991. Evolution of distinct populations of Puccinia recondita f. sp. tritici in Canada. Phytopathology 81:316-322.

15. Kolmer, J. A. 1992. Diversity of virulence phenotypes and effect of host sampling between and within populations of Puccinia recondita f. sp. tritici in Canada. Plant Dis. 76:618-621.

16. Kolmer, J. A. 1994. Physiologic specialization of Puccinia recondita $\mathrm{f}$. sp. tritici in Canada in 1993. Can. J. Plant Pathol. 16:326-328.

17. Kolmer, J. A. 1999. Physiologic specialization of Puccinia triticina in Canada in 1997. Plant Dis. 83:194-197.

18. Kolmer, J. A., Liu, J. Q., and Sies, M. 1995. Virulence and molecular polymorphism in Puccinia recondita f. sp. tritici in Canada. Phytopathology 85:276-285.

19. Leonard, K. J., Roelfs, A. P., and Long, D. L. 1992. Diversity of virulence within and among collections of Puccinia recondita f. sp. tritici in different areas of the United States. Plant Dis. 76:500-504.

20. Levine, M. N., and Hildreth, R. C. 1957. A natural occurrence of the aecial stage of Puccinia rubigo-vera var. tritici in the United States. Phytopathology 47:110-111.

21. Liu, J. Q., and Kolmer, J. A. 1998. Molecular and virulence diversity and linkage disequilibria in asexual and sexual populations of the wheat leaf rust fungus, Puccinia recondita. Genome 41:832-840.

22. Long, D. L., and Kolmer, J. A. 1989. A North American system of nomenclature for Puccinia recondita f. sp. tritici. Phytopathology 79:525-529.

23. Luig, N. H., Burdon, J. J., and Hawthorn, W. M. 1985. An exotic strain of Puccinia recondita tritici in New Zealand. Can. J. Plant Pathol. 7:173-176.

24. Park, R. F., and Felsenstein, F. G. 1998. Physiological specialization and pathotype distribution of Puccinia recondita in western Europe, 1995. Plant Pathol. 47:157-164.

25. Park, R. F., and Wellings, C. R. 1992. Pathogenic specialization of wheats rusts in Australia and New Zealand in 1988 and 1989. Australas. Plant Pathol. 21:61-69.

26. Saari, E. E., and Prescott, J. M. 1985. World distribution in relation to economic losses. Pages 259-298 in: The Cereal Rusts Vol. 1. A. P. Roelfs and W. R. Bushnell, eds. Academic Press, Orlando, FL.

27. Samborski, D. J. 1985. Wheat leaf rust. Pages 39-59 in: The Cereal Rusts Vol. 2. A. P. Roelfs and W. R. Bushnell, eds. Academic Press, Orlando, FL.

28. Sneath, P. A., and Sokal, R. R. 1973. Numerical Taxonomy. W. H. Freeman Co., San Francisco.

29. Sokal, R. R., and Rohlf, F. J. 1981. Biometry. W. H. Freeman, New York. 